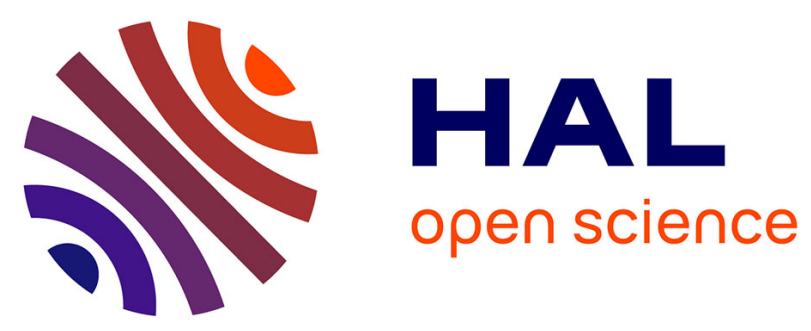

\title{
O-GlcNAcylation site mapping by (azide-alkyne) click chemistry and mass spectrometry following intensive fractionation of skeletal muscle cells proteins
}

Barbara Deracinois, Luc Camoin, Matthias Lambert, Jean -Baptiste Boyer, Erwan Dupont, Bruno Bastide, Caroline Cieniewski-Bernard

\section{To cite this version:}

Barbara Deracinois, Luc Camoin, Matthias Lambert, Jean -Baptiste Boyer, Erwan Dupont, et al.. O-GlcNAcylation site mapping by (azide-alkyne) click chemistry and mass spectrometry following intensive fractionation of skeletal muscle cells proteins. Journal of Proteomics, 2018, 186, pp.83-97. 10.1016/j.jprot.2018.07.005 . hal-02143569

\section{HAL Id: hal-02143569 \\ https://hal-amu.archives-ouvertes.fr/hal-02143569}

Submitted on 4 Jun 2019

HAL is a multi-disciplinary open access archive for the deposit and dissemination of scientific research documents, whether they are published or not. The documents may come from teaching and research institutions in France or abroad, or from public or private research centers.
L'archive ouverte pluridisciplinaire HAL, est destinée au dépôt et à la diffusion de documents scientifiques de niveau recherche, publiés ou non, émanant des établissements d'enseignement et de recherche français ou étrangers, des laboratoires publics ou privés. 


\section{O-GlcNAcylation site mapping by (azide-alkyne) click chemistry}

2 and mass spectrometry following intensive fractionation of

3 skeletal muscle cells proteins

4

5

6

7

8

9

10

11

12

Barbara Deracinois $^{1}$, Luc Camoin ${ }^{2}$, Matthias Lambert ${ }^{1}$, Jean-Baptiste Boyer ${ }^{2}$, Erwan Dupont ${ }^{1}$, Bruno Bastide $^{1}$ and Caroline Cieniewski-Bernard ${ }^{1, *}$

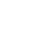
10

1 Univ. Lille, EA 7369 - URePSSS - Unité de Recherche Pluridisciplinaire Sport Santé Société, F59000 Lille, France

2 Aix Marseille Univ, CNRS, INSERM, Institut Paoli-Calmettes, CRCM, Marseille Protéomique, Marseille, France

*To whom correspondence should be addressed:

Dr Caroline Cieniewski-Bernard

URePSSS Unité de Recherche Pluridisciplinaire Sport, Santé, Société

EA7369 Laboratoire Activité Physique, Muscle et Santé

Eurasport - 413, avenue Eugène Avinée

59120 Loos - France

caroline.cieniewski-bernard@univ-lille.fr

\section{KEYWORDS}

O-GlcNAcylation; click chemistry; mass spectrometry; post-translational modifications; sites localization; skeletal muscle cells; fractionation. 


\section{ABSTRACT}

The O-linked-N-acetyl-D-glucosaminylation (O-GlcNAcylation) modulates numerous aspects of cellular processes. Akin to phosphorylation, O-GlcNAcylation is highly dynamic and reversible, and responds rapidly to extracellular demand. Despite the absolute necessity to determine posttranslational sites to fully understand the role of O-GlcNAcylation, it remains a high challenge for the major reason that unmodified proteins are in excess comparing to the O-GlcNAcylated ones. Based on a click chemistry approach, O-GlcNAcylated proteins were labelled with azido-GalNAc and coupled to agarose beads. The proteome extracted from $\mathrm{C} 2 \mathrm{C} 12$ myotubes was submitted to an intensive fractionation prior to azide-alkyne click chemistry. This combination of fractionation and click chemistry is a powerful methodology to map O-GlcNAc sites; indeed, 342 proteins were identified through the sequencing of 620 peptides containing one or more O-GlcNAc sites. We localized OGlcNAc sites on proteins involved in signalling pathways or in protein modification, as well as structural proteins. Considering the recent role of O-GlcNAcylation in the modulation of sarcomere morphometry and interaction between key structural protein, we focused on proteins involved in the cytoarchitecture of skeletal muscle cells. In particular, several O-GlcNAc sites were located into protein-protein interaction domain, suggesting that O-GlcNAcylation could be strongly involved in the organisation and reorganisation of sarcomere and myofibrils.

\section{SIGNIFICANCE}

O-GlcNAcylation is an atypical glycosylation involved in the regulation of almost all if not all cellular processes, but its precise role remains sometimes obscure because of the ignorance of the OGlcNAc site localization; thus, it remains indispensable to precisely map the O-GlcNAcylated sites to fully understand its role on a given protein. For this purpose, we combined extensive fractionation of skeletal muscle cells proteome with click chemistry to map O-GlcNAc sites without an a priori consideration. A total of 620 peptides containing one or more O-GlcNAc sites were sequenced; interestingly, several of them belong to low expressed proteins, in particular proteins involved in signalling pathways. We also focused on structural proteins in view of recent data supporting the role of O-GlcNAcylation in the modulation of sarcomere cytoarchitecture; importantly, some of the OGlcNAc sites were mapped into protein-protein interaction domain, reinforcing the involvement of OGlcNAcylation in the organisation and reorganisation of sarcomere, and in larger extent, of myofibrils. 
The O-N-acetyl- $\beta$-D-glucosaminylation, termed O-GlcNAcylation, is an atypical glycosylation corresponding to the transfer of a unique monosaccharide, the N-acetyl- $\beta$-D-glucosamine, on the hydroxyl group of serine and threonine amino acids of nuclear, cytosolic and mitochondrial proteins $(1,2)$. The O-GlcNAcylation has emerged as a key regulator of several cellular processes such as transcription, translation, regulation of signalling pathways, degradative processes, subcellular localization of targets, and so on (1,3-7). Because of its involvement in nearly all if not all cellular processes, O-GlcNAcylation is nowadays clearly associated with the aetiology of several acquired diseases, in particular diabetes, neuro-degenerative disorders, cardiovascular diseases or cancer (8).

The O-GlcNAcylated proteins bear similarities with the phosphorylated ones, in particular the reversibility of both processes since the phosphate and the GlcNAc moieties could be added and removed several times along the protein lifetime, and their turn-over is shorter than the protein backbone turn-over (9). The O-GlcNAcylation rapidly emerged as a major cellular mechanism which could compete with phosphorylation in terms of modified proteins and their importance in cellular physiology. But in contrast of the plethora of kinases and phosphatases responsible of the phosphorylation/ dephosphorylation process on specific proteins, a unique couple of antagonist enzymes (OGT/OGA) is involved in the O-GlcNAcylation process. While kinases recognize a consensus sequence, phosphorylation sites are easily predictable from primary sequence of a protein. However, no consensus sequence was clearly defined for OGT, but it appears that peptidic sequences modified by O-GlcNAcylation are enriched in small amino acids, with a proximal proline residue; these sequences also present preferential secondary structures such as loop and disorganized regions instead of $\alpha$-helix and $\beta$-strand (10-15). The O-GlcNAcylated sites could also correspond to phosphorylated ones; thus, many proteins are modified by both O-GlcNAc and phosphates groups, and these two post-translational modifications could compete to the same or to neighbouring sites $(4,16)$.

Despite the crucial role of O-GlcNAcylation in numerous cellular processes, the precise localization of O-GlcNAcylated sites remains an indispensable prerequisite for the fine understanding of its biological function. However, mapping the O-GlcNAcylated sites remains laborious but challenging, because of (i) the low stoichiometry of O-GlcNAcylation; (ii) the ion suppression of the modified peptide by the unmodified peptides present in large excess and (iii) the labile $\beta$ bond between serine or threonine and the O-GlcNAc moiety which is broken during the CID (Collision-Induced Dissociation) fragmentation process, leading to loss of site information during mass spectrometry analysis $(17,18)$.

Therefore, new strategies such as enrichment of O-GlcNAc modified proteins and the use of other fragmentation processes like ECD (Electron Capture Dissociation), ETD (Electron Transfer Dissociation), or HCD (High-energy Collisional Dissociation), able to limit the O-GlcNAc loss during the fragmentation, have been developed (19-21). Thus, enrichment step of O-GlcNAcylated pr oteins 
or tryptic peptides by immuno-affinity or affinity chromatography (in particular LWAC (lectin weak affinity chromatography)) were extensively used to identify O-GlcNAc sites (21-28), or combination of both approaches (29). Moreover, chemical-based enrichment using BEMAD ( $\beta$-Elimination followed by Michael Addition of Dithiothreitol (DTT)) was applied to O-GlcNAcylated proteins to overcome the O-GlcNAc loss during fragmentation, since labile peptide-GlcNAc bonds were substituted by no-labile peptide-DTT bonds (30-32). New strategies based on a chemoenzymatic label with galactosyltransferase $\left(\mathrm{GalT}^{\mathrm{Y} 289 \mathrm{~L}}\right)$ appeared during the last decade. Azido-modified N-acetylgalactosamine is transferred on the hydroxyl moiety of a GlcNAc acceptor allowing the fixation of aminooxy-biotin, and in consequence, the purification of O-GlcNAc proteins or peptides with streptavidin beads (33-36). Nevertheless, biotin fragmentation occurs during MS/MS fragmentation, leading to spectral analysis difficulties despite the stable GlcNAc (or more specifically LacNAcbiotin)-peptide bond (17). Moreover, the hard condition of elution, necessary to cut the biotinstreptavidin bond, can lead to peptide modifications and to low yield of the O-GlcNAcproteins/peptides purification (37). To overcome these problems, UV cleavable biotin can be used, this approach presenting the advantage to obtain positive charged peptides, leading to enhanced ETD fragmentation and O-GlcNAc site localization (38-41). It is worth to note that BEMAD and purification of biotin-labelled O-LacNAc peptides could be paired to localize O-GlcNAc sites (42-46).

We previously demonstrated that O-GlcNAcylation is an original and important regulator of skeletal muscle physiology $(47,48)$, in particular in the modulation of contractile activity $(49-52)$ as well as the morphometry of the sarcomere (53), supported by the fact that numerous contractile and structural proteins are O-GlcNAcylated $(50,54)$. Therefore, we developed an alternative strategy, specific, efficient and allowing purification of O-GlcNAc bearing proteins from skeletal muscle cells by the use, with minor changes, of the click chemistry methodology developed by Hahne and collaborators (55). Briefly, O-GlcNAc bearing proteins were linked to agarose beads through azidealkyne chemistry to enhance the enrichment of O-GlcNAcylated proteins. Proteolytic digestion of proteins linked to agarose beads and mass spectrometry analysis of resulting peptides provided the global identification of O-GlcNAcylated proteins. Analysis of released O-LacNAc peptides from agarose beads, resulting from a chemical cut-off of glycosidic bond, led to localization of the modified amino acids. To extensively map O-GlcNAc sites on proteins, we proposed herein an intensive fractionation of the muscle cell proteome according to solubility, hydrophobicity and isoelectric point of proteins prior to the click chemistry. Thus, the method of click chemistry was achieved (i) on whole proteome extracted from $\mathrm{C} 2 \mathrm{C} 12$ differentiated myotubes, (ii) on a subproteome, the cytosol-enriched extract, and (iii) on the cytosol-enriched extract extensively fractionated. The non-glycosylated peptides, and the glycosylated peptides released by beta-elimination, were analysed on mass spectrometry. Through the analysis of peptides retained on agarose beads, we identified $342 \mathrm{O}-$ GlcNAcylated proteins in the fractionated subproteome, corresponding to a 2-fold increase of the number of identified proteins from the whole extract, or a 3.5-fold increase of identified proteins from 
1 the non-fractionated subproteome, which reinforce the strength of the fractionation. Among these O-

2 GlcNAcylated proteins, we also sequenced 620 peptides containing one or several dehydrated serine 3 or threonine amino acids, corresponding so to O-GlcNAcylated sites. 


\section{EXPERIMENTAL SECTION}

Materials

Heat-inactivated horse serum (HI-HS), foetal bovine serum (FBS) and Dulbecco's Modified Eagle's Medium (DMEM) were purchased from GIBCO; antibiotic-antimycotic, GlycoProfile $\beta$ elimination kit and all analytical grade reagents from Sigma-Aldrich; anti-proteases (Complete EDTAfree) and anti-phosphatases (Phos-Stop) from Roche Diagnostic; Bradford and RC DCTM reagents protein assays, dithiothreitol, iodoacetamide, and stain-free gels from Bio-Rad; Zeba spin column from Thermo Fisher Scientific; IPG buffer from GE Healthcare; Click-It ${ }^{\mathrm{TM}}$ reagents from Molecular Probes; trypsin/Lys-C mix from Promega; $\lambda$ phosphatase and calf intestine phosphatase from New England Biolabs; C18 reversed-phase columns from Grace.

\section{Cell culture}

Mouse C2C12 skeletal myoblasts were obtained from ATCC (American Type Culture Collection). Myoblasts were grown on $100 \mathrm{~mm}$ Petri Dishes in proliferation medium (DMEM supplemented with $10 \%$ FBS and $1 \%$ antibiotic-antimycotic) at $37{ }^{\circ} \mathrm{C}$ in a humidified atmosphere of $5 \% \mathrm{CO}_{2}$ still reaching $90-95 \%$ confluence. They were then induced to differentiate into myotubes by switching to differentiation medium (DMEM containing 2\% HI-HS and 1\% antibiotic-antimycotic). Medium was changed every two-days, and myotubes were maintained for 5 days until they were mature.

\section{Cell harvesting and protein extraction}

C2C12 myotubes were rinsed three times with cold PBS and scraped with $2 \times 200 \mu 1$ of cold lysis RipA buffer (10 mM Tris/HCl, pH 7.4; 150 mM NaCl; 1 mM EDTA; $1 \%$ TritonX-100; 0.5\% sodium deoxycholate; $0.1 \%$ SDS) for whole extraction, or 2x150 $\mu$ l of cold CMM buffer (50 mM Tris/ $\mathrm{HCl}$, pH 7.4; 2 mM EDTA; 5 mM EGTA; 5mM DTT; 0.05\% saponin (w/v)) to get cytosol-enriched

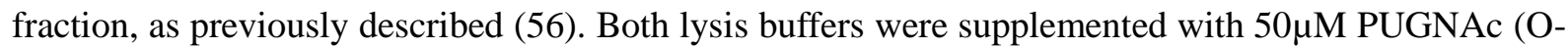
(2-acetamido-2-deoxy-D-glucopyranosilidene)amino-N-phenyl-carbamate), and proteases and phosphatases inhibitors. Collected materials were sonicated using Ultra-Sonic Cell Disruptor (Vibra Cell, $130 \mathrm{~W}$ ultrasonic processor); three pulses were performed at $70 \%$ of amplitude. Samples were then homogenized with gentle agitation for $1 \mathrm{~h}$ at $4{ }^{\circ} \mathrm{C}$ for RipA buffer in order to obtain the whole extract (WE), or centrifuged $\left(14,000 \mathrm{~g}, 4^{\circ} \mathrm{C}, 30 \mathrm{~min}\right.$ ) after lysis with $\mathrm{CMM}$ buffer in order to obtain the enriched-cytosolic fraction in the supernatant. The residual pellet was then resuspended in the CMM buffer added with $1 \%$ Triton X-100, homogenised, centrifuged; the supernatant, corresponding to membrane-enriched fraction, was kept. The Triton-insoluble pellet, corresponding to the myofilament-enriched fraction, was resuspended in RipA buffer. The protein content of all fractions 
(WE, cytosolic, membrane and myofilament fractions) was assayed using Bradford's method.

\section{Fractionation of the cytosolic extract}

Ammonium sulphate precipitation. One hundred milligrams of the protein extract were fractionated through 3-steps of ammonium sulphate (AS) precipitation. Briefly, extract was salted out with AS at $25 \%$ saturation for $2 \mathrm{~h}$ at $4^{\circ} \mathrm{C}$ and centrifuged $\left(10000 \mathrm{~g}, 4^{\circ} \mathrm{C}, 15 \mathrm{~min}\right)$. The pellet, which corresponds to the fraction AS25, was stored, while the supernatant was salted out with $50 \%$ saturation in AS. The third step corresponded to a precipitation with AS at $75 \%$ saturation. The three fractions obtained corresponded to AS25, AS50 and AS75 fractions, respectively. The pellets were solubilized by UTCD buffer (4M urea; 2M thiourea; $2 \%$ CHAPS (w/v); 5mM DTT), desalted with Zeba Spin columns, and assayed using reducing agent and detergent compatible protein assay (RC DCTM protein assay).

Liquid phase IEF. Each fraction resulting from ammonium sulphate precipitation was submitted to liquid phase IEF using the MicroRotofor cell equipped with the PowerPac HV power supply, according to manufacturer (Bio-Rad). Protein samples (36 mg in total by fraction separated in 12 samples of $3 \mathrm{mg}$ ) were diluted at $1 \mathrm{mg} / \mathrm{ml}$ in UTCD buffer added with 3\% ampholyte-IPG buffer $\mathrm{pH}$ 4-7, and loaded to pre-assembled focusing chamber of the MicroRotofor cell. The ion exchange membranes, separating the electrode reservoirs and the focusing chamber, were equilibrated in $0.1 \mathrm{M}$ $\mathrm{H}_{3} \mathrm{PO}_{4}$ and $0.1 \mathrm{M} \mathrm{NaOH}$ for cation exchange membrane and anion exchange membrane, respectively. The focusing run was performed with constant power at $1 \mathrm{~W}$ at $10^{\circ} \mathrm{C}$. The separation typically occurred for $2.5 \mathrm{~h}$ and was terminated 30 minutes after the voltage stabilizes. After focusing, 10 fractions of $200 \mu \mathrm{l}$ (annotated F1 to F10 from the more acidic fraction to the more basic fraction) were quickly collected to avoid diffusion with the use of a vacuum. The $\mathrm{pH}$ of the individual fractions was measured with a $\mathrm{pH}$ meter, and fractions were kept at $-20^{\circ} \mathrm{C}$ before further analysis.

\section{One-dimensional polyacrylamide gel electrophoresis (1D-PAGE)}

Twenty micrograms of each fraction (of $10 \mu \mathrm{l}$ in case of IEF fractionation) were boiled in Laemmli buffer $(62.5 \mathrm{mM}$ Tris/HCl, $\mathrm{pH}$ 6.8; $10 \%$ glycerol; 2\% SDS; 5\% ß-mercaptoethanol; $0.02 \%$ bromophenol blue) and separated electrophoretically on $7.5 \%$ or on any kD Mini-PROTEAN TGX Stain-Free ${ }^{\mathrm{TM}}$ (SF) Precast Gels (25 min, $300 \mathrm{~V}$ ). The SF imaging was performed with ChemiDoc MP Imager and Image Lab 4.0.1 software (Bio-Rad); a 5-min activation time was used for the whole protein pattern imaging.

\section{O-GlcNAc proteins enrichment}

Click chemistry (azide/alkyne click reaction and enrichment) was performed on whole extract as 
well as on cytosol-enriched extract using the Click-iT ${ }^{\mathrm{TM}}$ O-GlcNAc Enzymatic Labelling System and the Click-iT ${ }^{\mathrm{TM}}$ Protein Enrichment Kit according to the manufacturer's instructions and to the protocol described by Hahne and coworkers (55). The click chemistry protocol was also applied on each fraction issued from the MicroRotofor runs (themselves issued from ammonium sulphate precipitation of cytosol-enriched proteins); a total of 30 fractions were labelled. It is worth to note that for each sample, the same protein quantity (i.e. $2 \mathrm{mg}$ ) was used for the click chemistry-based enrichment.

After chloroform/methanol precipitation, performed at room temperature, the O-GlcNAc proteins were labelled overnight at $4^{\circ} \mathrm{C}$ with the Click-iT ${ }^{\mathrm{TM}}$ O-GlcNAc Enzymatic Labelling System. Briefly, Gal-T1 (Y289L) was incubated with proteins in labelling buffer (20 mM HEPES, pH 7.9; $50 \mathrm{mM}$ $\mathrm{NaCl} ; 2 \% \mathrm{NP}-40 ; 5.5 \mathrm{mM} \mathrm{MnCl}_{2} ; 25 \mu \mathrm{M}$ UDP-GalNAz), according to manufacturer's recommendations. All reagents were provided in the kit, but the volume of each reagent was adjusted according to protein quantities. Reaction was performed at $4{ }^{\circ} \mathrm{C}$ under gentle agitation for $20 \mathrm{~h}$, and then azide-labelled proteins were chloroform/methanol precipitated.

The azide-labelled proteins were then resuspended in urea lysis buffer, according to manufacturer's recommendations, following by an extensive homogenization. The proteins samples were then centrifuged at $10000 \mathrm{rcf}$ for $5 \mathrm{~min}$ in order to discard the insoluble material. The LacNAz-proteins were then precleared with agarose resin for $1 \mathrm{~h}$, and the supernatant was then added with catalyst solution provided into the Click-iT ${ }^{\mathrm{TM}}$ Protein Enrichment Kit, containing copper (II) sulphate for a final concentration of $50 \mathrm{mM}$. The azide-labelled proteins were then incubated on an end-over-end rotator at room temperature for $18 \mathrm{~h}$ with $200 \mu \mathrm{L}$ slurry of alkyne agarose resin according to the Click$\mathrm{iT}^{\mathrm{TM}}$ Protein Enrichment Kit. After overnight click reaction, the supernatant was discarded and the resin was subjected to washes with $3 \times 1.5 \mathrm{~mL} 10 \mathrm{mM}$ diethylene triamine pentaacetic acid (DPTA) and $2 \times 1.5 \mathrm{~mL}$ of MS grade water. Following reduction (10 mM dithiothreitol [DTT], $\left.30 \mathrm{~min}, 55^{\circ} \mathrm{C}\right)$ and alkylation (50 mM iodoacetamide [IAA], $60 \mathrm{~min}, \mathrm{RT}$ ), the resin was subjected to an extensive washing procedure performed in column as follow: 5 x $2 \mathrm{~mL}$ SDS wash buffer $(100 \mathrm{mM}$ Tris/ $\mathrm{HCl}, \mathrm{pH}$ 8; $1 \%$ SDS; $250 \mathrm{mM} \mathrm{NaCl} ; 5 \mathrm{mM}$ EDTA); 5 x $2 \mathrm{~mL}$ urea buffer ( $8 \mathrm{M}$ urea; $100 \mathrm{mM}$ Tris/HCl, $\mathrm{pH}$ 8); $10 \times 2 \mathrm{~mL} 20 \%$ acetonitrile; 2 x $1 \mathrm{~mL}$ digestion buffer (100 mM Tris/HCl, $\mathrm{pH} 8.2 ; 2 \mathrm{mM} \mathrm{CaCl}$; $10 \%$ $\mathrm{ACN}$ ). Digestion of resin-bound proteins was performed o/n in $200 \mu \mathrm{L}$ digestion buffer containing 1 $\mu \mathrm{g}$ of trypsin/Lys-C mix. Following the on-resin digestion, the remaining solution was discarded, and the resin washed with $500 \mu \mathrm{L}$ of digestion buffer; both solutions, corresponding to non-retained peptides (NR peptides, i.e. the non-linked peptides), were pooled together and stored before desalting. The resin was then washed twice with $1.5 \mathrm{~mL}$ of MS grade water, following by $2 \times 1.5 \mathrm{~mL}$ washes with dephosphorylation buffer (50 mM Tris/HCl, pH 7.6; $100 \mathrm{mM} \mathrm{NaCl} ; 1 \mathrm{mM}$ DTT; $10 \mathrm{mM} \mathrm{MgCl}$; $1 \mathrm{mM} \mathrm{MnCl} 2$ ).

Peptides-linked to agarose beads were submitted to dephosphorylation at $37^{\circ} \mathrm{C}$ for $6 \mathrm{~h}$ in $400 \mu \mathrm{L}$ of dephosphorylation buffer using $800 \mathrm{U} \lambda$ phosphatase and $20 \mathrm{U}$ calf intestine phosphatase. Following dephosphorylation, the resin was washed twice with $1.8 \mathrm{~mL}$ of $\mathrm{H}_{2} \mathrm{O}$, and the slurry volume was 
adjusted to $300 \mu \mathrm{L}$ with $\mathrm{H}_{2} \mathrm{O}$ before $\beta$-elimination with the GlycoProfile $\beta$-elimination kit. The $\beta$ elimination reaction was incubated on an end-over-end shaker with extensive mixing at $4{ }^{\circ} \mathrm{C}$ and quenched after $24 \mathrm{~h}$ with 1\% TFA until pH6-8. Agarose beads were discarded, and the resulting solution contained the $\beta$-eliminated peptides which correspond to the initially O-GlcNAcylated peptides. The non-retained and the $\beta$-eliminated peptides were desalted with $\mathrm{C} 18$ reversed-phase columns and drained by vacuum concentrator before mass spectrometry analysis.

\section{Mass spectrometry}

Samples were reconstituted with $0.1 \%$ trifluoroacetic acid in $4 \%$ acetonitrile and analysed by liquid chromatography (LC)-tandem mass spectrometry (MS/MS) using a nanoLC Ultimate 3000 chromatography system (Dionex, Sunnyvale, CA) coupled to an LTQ-Orbitrap-Velos or a Q-Exactive mass spectrometer (Thermo Electron, Bremen, Germany). Peptides were separated on a Dionex Acclaim PepMap RSLC C18 column. First, peptides were concentrated and purified on a pre-column from Dionex (C18 PepMap100, 2 cm x $100 \mu \mathrm{m}$ I.D, $100 \AA$ A pore size, $5 \mu \mathrm{m}$ particle size) in solvent A ( $0.1 \%$ formic acid in $2 \%$ acetonitrile). In the second step, peptides were separated on a reverse phase column from Dionex (C18 PepMap100, $15 \mathrm{~cm}$ x $75 \mu \mathrm{m} \mathrm{I.D,} 100 \AA$ A pore size, $2 \mu \mathrm{m}$ particle size) at $300 \mathrm{~nL} / \mathrm{min}$ flow rate. After column equilibration using $4 \%$ of solvent B (20\% water - $80 \%$ acetonitrile - $0.1 \%$ formic acid), peptides were eluted from the analytical column by a two-steps linear gradient (4$20 \%$ acetonitrile $/ \mathrm{H}_{2} \mathrm{O} ; 0.1 \%$ formic acid for $90 \mathrm{~min}$ and $20-45 \%$ acetonitrile/ $\mathrm{H}_{2} \mathrm{O} ; 0.1 \%$ formic acid during $30 \mathrm{~min}$ for the LTQ-Orbitrap Velos and 4-25\% acetonitrile/H2O; 0.1\% formic acid for $40 \mathrm{~min}$ and $25-50 \%$ acetonitrile/H2O; $0.1 \%$ formic acid during $10 \mathrm{~min}$ for the Q-Exactive). For peptide ionisation in the nanospray source, spray voltage was set between 1.4 and $1.5 \mathrm{kV}$ and the capillary temperature at $275{ }^{\circ} \mathrm{C}$. The LTQ-Orbitrap-Velos was set up in data dependent mode to switch consistently between MS and MS/MS. MS spectra were acquired with the Orbitrap in the range of $\mathrm{m} / \mathrm{z}$ 400-1700 at a FWHM resolution of 60000 measured at $400 \mathrm{~m} / \mathrm{z}$ and an automatic gain control (AGC) target value of 1e6. For internal mass calibration the 445.120025 ion was used as lock mass. The 20 abundant precursor ions were selected and collision-induced dissociation fragmentation with 35\% normalized collision energy (NCE), and an AGC target value of 1e4 was performed in the ion trap on the 20 most intense precursor ions measured to have maximum sensitivity and yield a maximum amount of MS/MS data. The signal threshold for an MS/MS event was set to 500 counts. Charge state screening was enabled to exclude precursors with 0 and 1 charge states. Dynamic exclusion was enabled with a repeat count of 1, exclusion list size 500 and exclusion duration of 30 s. For Q-Exactive runs, survey MS scan were acquired in the Orbitrap on the 300-1700 m/z range with a resolution of 70 000 (AGC target at 1e6), the 12 most intense ions per survey scan (Intensity threshold 1e5) were selected for HCD fragmentation (AGC target 5e5, NCE 25\%) and resulting fragments were analysed at a resolution of 17500 in the Orbitrap. Fragmented precursor ions were dynamically excluded for 25 


\section{Protein identification}

4 The acquired raw LC Orbitrap MS data were processed using Proteome Discoverer 1.4.1.14 5 (Thermo Fisher Scientific). This software was used to search data via in-house Mascot server (version 6 2.3.0; Matrix Science, London, U.K.) and SEQUEST HT against the Uniprot mouse reference 7 proteome database (version 09.08.2013, 50,850 entries). The following parameters were used for 8 searches: (i) trypsin; (ii) two missed cleavages were allowed; (iii) monoisotopic precursor tolerance of $98 \mathrm{ppm}$, followed by $0.8 \mathrm{Da}$ for fragment ions from MS/MS; and (iv) cysteine carbamidomethylation $(+57.0215)$ and methionine oxidation $(+15.995)$ as variable modifications. The false discovery rate (FDR) was processed the built-in Percolator and was set to 5\% (57). Protein identification from Belimination experiments was performed similarly as above for data processing with the exception of the following modifications. Dehydration of Ser and Thr (-18.011) as well as B-elimination of Cys ($33.988 \mathrm{Da}$ ) was added as variable modification. The mass spectrometry proteomics data have been deposited to the ProteomeXchange Consortium via the PRIDE (58) partner repository with the dataset identifier PXD004860.

\section{Bioinformatics resources and protein lists}

Protein lists were compared using nwCompare software (59). All identified proteins were converted into gene names and classified into families and subfamilies of shared function, which were then categorized by molecular function and biological process ontology terms in the Protein Analysis Through Evolutionary Relationships (PANTHER) classification system (www.pantherdb.org) (60-62). 


\section{RESULTS}

\section{Fractionation of cytosol-enriched fraction from $\mathrm{C} 2 \mathrm{C} 12$ myotubes}

The workflow applied in our study was presented on Fig.1. Thus, whole proteins were extracted from $\mathrm{C} 2 \mathrm{C} 12$ differentiated myotubes (Whole Extract, WE), or submitted to successive fractionation steps as described on Fig.1; the protein profiles of the resulting fractions were shown on Fig.2. Briefly, a differential protocol of extraction was applied to recover a cytosol-enriched fraction (CYT), a membrane-enriched fraction (MB) and a myofilament-enriched fraction (MYO); these fractions contained $64.2 \%, 18.9 \%$ and $16.9 \%$ of WE proteins, respectively (Fig.2A). It is noteworthy that the profile of cytosol-enriched fraction was quite similar than those corresponding to whole extract (Fig.2A). This fraction was then submitted to two successive fractionation protocols, while the membrane- and the myofilament-enriched fractions were discarded from the following analysis for the main reason that these fractions were poorly resolubilized following the chloroform/methanol precipitation.

The cytosol-enriched fraction was firstly partitioned through ammonium sulphate (AS) precipitation. Four fractions were obtained, annotated as AS25, AS50, AS75 and AS100 according to the final percentage of ammonium sulphate, as indicated on Fig.2B. The protein profile of each fraction was shown on Fig.2B; 37.9\%, 43.9\%, 17.4\% and 0.8\% of the non-fractionated CYT proteins were obtained for AS25, AS50, AS75 and AS100 fractions, respectively. Because of the poor protein content on AS100 fraction, it was discarded from the resting analysis. A second fractionation was done on the AS25, AS50 and AS75 fractions, based on the separation of proteins according to their isoelectric point, using the MicroRotofor apparatus. Ten fractions were obtained in each case, containing on average $1.7 \%, 3.6 \%, 4.7 \%, 5 \%, 7 \%, 10.6 \%, 9.9 \%, 9.8 \%, 16.5 \%$ and $31.2 \%$ from $\mathrm{F} 1$ (the more acidic fraction) to F10 (the more basic fraction). The corresponding $\mathrm{pH}$ for each fraction was indicated on supplemented Table I. As shown on Fig.2C, the fractions F1 to F3 (pH 4.42 to 5.19) contained very few proteins comparing with the following fractions. In contrast, the neutral fractions (F7 to F10, pH 6.18 to 8.01 ) contained together approximately $59.7 \%, 68.5 \%$ and $73.8 \%$ of the AS25, AS50 and AS75 fractions, respectively.

At least, a total of 30 fractions were obtained for cytosol-enriched fractions (fCYT). Each of them, as well as non-fractionated cytosol-enriched fraction (CYT) and whole extract (WE), were submitted to click chemistry protocol in order to map the O-GlcNAc sites. These fractions, submitted to labelling-coupling protocol and analysed on mass spectrometry, were indicated in bold italic on Fig.1.

\section{Efficiency of the O-GIcNAcylation mapping after extensive fractionation}


The improvement of the fractionation on O-GlcNAcylation mapping was demonstrated in table I, which indicated the number of the sequenced peptides and the resulting identified proteins. Data were expressed for the peptides which were not linked to agarose beads (corresponding to non-OGlcNAcylated peptides, but which belong to the O-GlcNAcylated proteins coupled to agarose beads), as well as for peptides which were linked to agarose beads (corresponding to O-GlcNAcylated peptides covalently linked to agarose beads and released from beads by beta-elimination). We also indicated the percentage of peptides containing one or more dehydrated serine or threonine (corresponding so to peptides containing one or more O-GlcNAc sites). Data were presented for the non-fractionated $\mathrm{C} 2 \mathrm{C} 12$ extract (WE, whole extract), the non-fractionated cytosol-enriched extract (CYT), and the fractionated cytosol-enriched extract (CYT-AS-IEF combined fractions, corresponding to fCYT fraction). Based on these data, we determined the efficiency factor as the ratio of identified peptides/proteins after extensive fractionation (fCYT fraction) comparing with the non-fractionated cytosol-enriched extract (CYT).

We firstly analysed the non-linked peptides to order to identify the O-GlcNAcylated proteins linked to agarose beads, independently of their O-GlcNAc sites. In the non-fractionated whole extract, 554 proteins were identified, while 449 were identified in the cytosol-enriched fraction. Once the fractionation protocol applied, the number of identifications was increased by a factor 3 comparing with CYT fraction since 1362 proteins were identified in fCYT fraction. It is worth to note that 14573 peptides (containing 9.3\% of dehydrated peptides) led to the identification of these $1362 \mathrm{O}$ GlcNAcylated proteins, while "only" 5540 peptides (containing $6.2 \%$ of dehydrated peptides) were identified in the non-fractionated cytosol-enriched fraction. Thus, three times more peptides were identified when extensive fractionation was applied on CYT fraction. Interestingly, we identified 620 contained one or more dehydrated serine or threonine (corresponding so to O-GlcNAc sites) derived from the beta-elimination (BE) of peptides covalently linked to agarose beads; in parallel, 311 and 142 dehydrated peptides were identified in WE and CYT fractions. Thus, extensive fractionation of cytosol enriched-fraction increased the number of identified peptides bearing one or more O-GlcNAc site(s) by a factor 4.4 compared with non-fractionated cytosol-enriched fraction. It should be mentioned that among the peptides identified in the beta-eliminated peptides fractions, some of them were not dehydrated, suggesting that some peptides remained aspecifically retained on agarose beads despite the pre-clearing step with agarose beads to avoid the non-specific retention of proteins on agarose beads, and despite the extensive washing steps applied to abrogate protein-protein interaction and so to eliminate the proteins which were not covalently linked to agarose beads.

All data files corresponding to the identification of proteins and the peptides sequenced were presented as supplemental data (Supplemented Table II to VII, for WE_BE, WE_NR, CYT_BE, CYT_NR, fCYT_BE and fCYT_NR, respectively); all mass spectrometry data were deposited to the ProteomeXchange Consortium via the PRIDE partner repository $(58,63)$ with the dataset identifier PXD004860. 


\section{Global analysis of O-GlcNAcylated proteins and focus on particular protein classes}

As indicated in Table I, 342 proteins were identified consecutively to the sequencing of peptides released from agarose beads by beta-elimination, i.e. threefold than those identified in non-fractionated CYT fractions. We classified these proteins using the PANTHER classification system (Protein Analysis THrough Evolutionary Relationships, http://www.pantherdb.org/) (64, 65). Thus, proteins were classified according to their molecular function (Fig.3A) or the protein class (Fig.3B). Among the classified proteins according to their molecular function, $44.1 \%$ had a binding activity, $27.8 \%$ a catalytic activity, and $16.8 \%$ a structural molecule activity; the other proteins, represented less than $5 \%$, had transporter, translation regulator, channel regulator, receptor, signal transducer or antioxidant activities. Proteins were also classified according to the class they belong: nucleic acid metabolism (32.5\%), enzymatic activities (27.7\%), cytoskeletal proteins and chaperones (14.5\%), signalling proteins $(7.3 \%)$, structural proteins $(5.7 \%)$, transporter and binding proteins $(5.3 \%)$, or cell adhesion molecule (4.4\%); $2.6 \%$ of proteins (others) were not assigned to the classes of proteins described just above.

We focused on proteins identified through the sequencing of beta-eliminated peptides containing one or several dehydrated serine and threonine. We mapped the O-GlcNAcylation site(s) (indicated in bold and underlined in peptide sequence) within different classes of proteins, in particular those involved in cytoskeleton and sarcomeric organization (Table II) or involved in signalling pathways, in protein degradation and in protein post-translational modification (Table III). Table II combined (i) cytoskeleton proteins and proteins involved in cytoskeleton organization; (ii) actin cytoskeleton organization and reorganization; (iii) proteins involved in sarcomeric organization, motor activity and contractile fibers proteins; (iv) microtubules cytoskeleton organization and reorganization; (v) chaperones; (vi) intermediate filament proteins; and (vii) cell adhesion molecules. Table III combined (i) proteins involved in signalling or apoptotic pathways; (ii) proteins involved in protein modification (such as phosphorylation, ubiquitination, SUMOylation); and (iii) proteins involved in protein degradation or autophagy. Classification was done according to gene ontology annotation indicated in UniProtKB (http://www.uniprot.org) or GeneCards database (http://www.genecards.org/). We indicated the fraction (WE, CYT, fCYT) in which the peptides were identified. As shown on these tables, some peptides were identified in all fractions; in contrast, a large number of them were only identified when cytosolic-enriched extract was extensively fractionated. We also observed that in some case, within the same peptide, serine or threonine residues were differently dehydrated (for example, this was particularly observed for the Nascent polypeptide-associated complex subunit alpha, in Table III). 


\section{DISCUSSION}

Mapping O-GlcNAc sites is a crucial point to characterize the role of O-GlcNAcylation on a given protein; indeed, the identification of the O-GlcNAc site within a specific domain of a protein could bring arguments to make hypothesis and determine strategies to clearly demonstrate and understand the role of the monosaccharide in the modulation of the function of a protein of interest. Strategies based on copper-catalysed azide/alkyne click chemistry emerged during the last decade; Hahne and collaborators improve and validate this method permitting the linkage of O-GlcNAcylated proteins to agarose beads to enrich the modified proteins, to identify them, and to map the O-GlcNAc sites (55). Beside the method, we opted for the enzymatic labelling of O-GlcNAcylated proteins rather than metabolic labelling since GlcNAz incorporation preferentially occurs in complex glycans (66). We added several steps of fractionation prior to the click chemistry; from the analysis of linked peptides on agarose beads and released from beads by beta-elimination, we identified 342 proteins in the fractionated subproteome, corresponding to a 3.5-fold increase of identified proteins compared with a non-fractionated cytosol-enriched fraction. Indeed, through the fractionation protocol, based on the physicochemical properties of proteins, the sample is made less complex. Thus, there is an enrichment of certain proteins that could not have been identified in a complex mixture. As consequence, the number of identified peptides/proteins increased after fractionation. We also sequenced 620 peptides containing one or several O-GlcNAcylated sites. Over increasing the number of identified peptides/proteins, the fractionation protocol performed prior to click chemistry led to the mapping of O-GlcNAc sites on numerous signalling proteins, such as proteins involved in MAPK pathway, including the TGF-beta pathway. In addition, we identified several proteins involved in the ubiquitination process, in particular several E3-ubiquitin ligases, as well as proteins responsible of deubiquitination. Thus, our data suggest that modulation of ubiquitination through O-GlcNAcylation could be involved in the modulation of degradative process (and so in the regulation of protein homeostasis essential for muscle healthcare), as well as intracellular processes modulated by ubiquitination. It is worth to note that we opted for fractionation according to ionic force or isoelectric point; of course, it could be envisaged to apply other protocols of fractionation to yield complementary data to complete the non-exhaustive list of O-GlcNAcylated peptides.

About fifteen years ago, we attempted to cartography the O-GlcNAcylated proteins in skeletal muscle and we identified structural proteins, proteins involved in signalling pathways and contractile proteins as being O-GlcNAcylated (54). Five O-GlcNAc sites were mapped on actin and myosin using a BEMAD approach, and interestingly, some of them were located into or close to protein-protein interaction domain, suggesting that O-GlcNAcylation could play an important role in the modulation of sarcomeric protein interaction (32). In this way, we recently demonstrated that O-GlcNAcylation was a key modulator of sarcomere morphometry, in particular through the modulation of protein- 
protein interaction within multiprotein complexes including key structural proteins such as desmin, $\alpha \mathrm{B}$-crystallin, $\alpha$-actinin, filamin-C and moesin (53). In addition, we showed that, consecutively to global changes of O-GlcNAcylation level, the interaction between desmin and $\alpha \mathrm{B}$-crystallin was modulated; in this paper, we localized the O-GlcNAc sites of these two proteins. For desmin, a protein of intermediate filament essential for striated muscle cells integrity, GlcNAcylation site was localized on the serine 459, in the C-terminal domain or tail domain (67), suggesting a key role of this OGlcNAcylation on the function of the protein. Indeed, this domain is involved in the head to tail longitudinal assembly of desmin tetramers, and controls the lateral packing and the elongation and stabilization of mature desmin filaments (68). In addition, this domain is also involved in the interaction between desmin and cytoskeletal protein partners, leading to the formation of a highly complex network of intermediate filaments (69). Moreover, the mutation of this site (corresponding to serine 460 for human desmin) leads to particular myofibrillar myopathies, i.e. desminopathies, characterized by the disintegration of desmin filament, the accumulation of insoluble protein aggregates (including some of the protein partners of desmin such as $\alpha \mathrm{B}$-crystallin), and at terms, to the destructuration of myofibrils (70). In transfected SW13 human cells and $\mathrm{C} 2 \mathrm{C} 12$ murine cells, the mutation S460I led to short desmin filaments, with irregular diameter, and numerous aggregates randomly distributed in cytoplasm (70).

Desmin integrity is regulated by chaperones; among them, the $\alpha \mathrm{B}$-crystallin plays a crucial role in the localization or stabilization of cytoskeleton element (71), and in particular, desmin filaments (72). Thus, the $\alpha \mathrm{B}$-crystallin modulates the polymerization of desmin filaments and prevent their aggregation $(73,74)$; in addition, it decreases the desmin interfilament interaction in vitro (75). The interaction between desmin and its molecular chaperone involved three domains on $\alpha B$-crystallin : the $\beta 3$ and $\beta 8$ sheets, and the 155-165 C-terminal residues (76). We have localized the O-GlcNAc moiety on the threonine 162 , i.e. in one of the interaction domain of $\alpha \mathrm{B}$-crystallin with desmin. Interestingly, the mutation of the C-terminal domain of the chaperone is closely associated to an increase of association and aggregation of desmin filaments (76). It is worth to note that on $\alpha \mathrm{A}$-crystallin and on HSPB1, O-GlcNAc sites were also localized on the C-terminal domain, which corresponds to a flexible conserved domain common to sHSPs, essential to maintain sHSP solubility, stability and chaperone activity (77). All together, these data strongly support that O-GlcNAcylation may be a key regulator of desmin- $\alpha \mathrm{B}$-crystallin interaction. Interestingly, it was demonstrated that stress induced changes of O-GlcNAcylation level of $\alpha \mathrm{B}$-crystallin, associated to translocation of $\alpha \mathrm{B}$-crystallin to cytoskeleton (71).

The role of O-GlcNAcylation in the maintenance of sarcomere cytoarchitecture and in modulation of interactions between structural and/or sarcomeric proteins was also supported by other data gained from this study. Indeed, on another chaperone involved in the maintenance of sarcomere integrity and in the turn-over of Z-line proteins (78, 79), BAG3 (Bcl-2-associated athanogene 3), two O- 
1 GlcNAcylated sites out of the four are located into the PxxP domain, which is known to interact with

2 SH3-containing proteins (80). Titin, essential for assembling and maintenance of sarcomere, providing

3 to myofibril their property of elasticity (81), is O-GlcNAcylated on T24950 and S24954, localized in

4 the mouse domain Kelch-12 (corresponding to the human domain Ig-like 123), which is the interaction

5 domain with protein partners such as myosin or My-BPC (82). Plectin, a large intermediate filament-

6 associated protein acting as cytoskeletal crosslinker and signalling scaffold, is O-GlcNAcylated into

7 the plakin domain repeat B5 $(83,84)$, located at the C-terminal domain of plectin and described to

8 bind to various intermediate filament proteins (85).

9 To sum, while our data demonstrated that the combination of fractionation and click chemistry was

10 a powerful methodology to map O-GlcNAc sites on several proteins involved in signalling pathways

11 or in protein modification (in particular ubiquitination), as well as structural proteins, it brought strong arguments in favour of the essential role of O-GlcNAcylation for the sarcomeric cytoarchitecture of skeletal muscle cells. Thus, we identified herein several key structural proteins involved in the maintenance of filament networks permitting force development and providing muscle cells mechanical strength. Moreover, we localized numerous O-GlcNAcylated sites in protein-protein interaction domains. In addition, key structural proteins such as desmin, $\alpha \mathrm{B}$-crystallin, plectin, or BAG3 among others are O-GlcNAcylated; importantly, mutation that can occur at the OGlcNAcylated sites of these proteins led to the sarcomere disorganisation and myofibrils destructuration because of the loss of protein-protein interactions; as consequence, proteins aggregate, resulting at terms to myofibrillar myopathies. 


\section{CONFLICT OF INTEREST}

2 The authors declare that they have no conflict of interest.

4

5

6

7

8

9

10

\section{ACKNOWLEDGMENT}

This research was funded by the French National Research Agency (ANR, Agence Nationale de la Recherche, Young Researchers Program, n¹1JSV8 006 01). Barbara Deracinois is a recipient of a fellowship from ANR. The proteomic analyses were done using the mass spectrometry facility of Marseille Proteomics (http://map.univmed.fr/) supported by IBISA (Infrastructures Biologie Santé et Agronomie), the Cancéropôle PACA, the Provence-Alpes-Côte d'Azur Region, the Institut PaoliCalmettes and the Centre de Recherche en Cancérologie de Marseille. The mass spectrometry proteomics data, including search result files have been deposited to the ProteomeXchange Consortium (www.proteomexchange.org) via the PRIDE partner repository with the dataset identifier PXD004860. 
1. Hart, G. W., Three Decades of Research on O-GlcNAcylation - A Major Nutrient Sensor That Regulates Signaling, Transcription and Cellular Metabolism. Front Endocrinol. (Lausanne) 2014, $5,183$.

2. Torres, C. R.; Hart, G. W., Topography and polypeptide distribution of terminal Nacetylglucosamine residues on the surfaces of intact lymphocytes. Evidence for O-linked GlcNAc. J. Biol. Chem 1984, 259, (5), 3308-3317.

3. Banerjee, P. S.; Ma, J.; Hart, G. W., Diabetes-associated dysregulation of O-GlcNAcylation in rat cardiac mitochondria. Proc. Natl. Acad. Sci. U. S. A 2015, 112, (19), 6050-6055.

4. Hardiville, S.; Hart, G. W., Nutrient regulation of signaling, transcription, and cell physiology by O-GlcNAcylation. Cell Metab 2014, 20, (2), 208-213.

5. Hart, G. W.; Housley, M. P.; Slawson, C., Cycling of O-linked beta-N-acetylglucosamine on nucleocytoplasmic proteins. Nature 2007, 446, (7139), 1017-1022.

6. Hart, G. W.; Slawson, C.; Ramirez-Correa, G.; Lagerlof, O., Cross talk between O-GlcNAcylation and phosphorylation: roles in signaling, transcription, and chronic disease. Annu. Rev. Biochem 2011, 80, 825-858.

7. Harwood, K. R.; Hanover, J. A., Nutrient-driven O-GlcNAc cycling - think globally but act locally. J. Cell Sci 2014, 127, (Pt 9), 1857-1867.

8. Bond, M. R.; Hanover, J. A., A little sugar goes a long way: the cell biology of O-GlcNAc. J Cell Biol 2015, 208, (7), 869-880.

9. Hart, G. W.; Akimoto, Y., The O-GlcNAc modification. In Essentials of Glycobiology, 2nd edition, 2009; Vol. Chapter 18, p Cold Spring Harbor (NY): Cold Spring Harbor Laboratory Press.

10.Chen, Y. X.; Du, J. T.; Zhou, L. X.; Liu, X. H.; Zhao, Y. F.; Nakanishi, H.; Li, Y. M., Alternative OGlcNAcylation/O-phosphorylation of Ser16 induce different conformational disturbances to the N terminus of murine estrogen receptor beta. Chem. Biol 2006, 13, (9), 937-944.

11.Nishikawa, I.; Nakajima, Y.; Ito, M.; Fukuchi, S.; Homma, K.; Nishikawa, K., Computational prediction of O-linked glycosylation sites that preferentially map on intrinsically disordered regions of extracellular proteins. Int. J. Mol. Sci 2010, 11, (12), 4991-5008.

12.Xie, H.; Vucetic, S.; Iakoucheva, L. M.; Oldfield, C. J.; Dunker, A. K.; Uversky, V. N.; Obradovic, Z., Functional anthology of intrinsic disorder. 1. Biological processes and functions of proteins with long disordered regions. J. Proteome. Res 2007, 6, (5), 1882-1898.

13.Xie, H.; Vucetic, S.; Iakoucheva, L. M.; Oldfield, C. J.; Dunker, A. K.; Obradovic, Z.; Uversky, V. N., Functional anthology of intrinsic disorder. 3. Ligands, post-translational modifications, and diseases associated with intrinsically disordered proteins. J. Proteome. Res 2007, 6, (5), 1917-1932.

14. Yang, W. H.; Kim, J. E.; Nam, H. W.; Ju, J. W.; Kim, H. S.; Kim, Y. S.; Cho, J. W., Modification of p53 with O-linked N-acetylglucosamine regulates p53 activity and stability. Nat. Cell Biol 2006, 8, (10), 1074-1083.

15.Lazarus, M. B.; Nam, Y.; Jiang, J.; Sliz, P.; Walker, S., Structure of human O-GlcNAc transferase and its complex with a peptide substrate. Nature 2011, 469, (7331), 564-567.

16.Zeidan, Q.; Hart, G. W., The intersections between O-GlcNAcylation and phosphorylation: implications for multiple signaling pathways. J. Cell Sci 2010, 123, (Pt 1), 13-22.

17.Hu, P.; Shimoji, S.; Hart, G. W., Site-specific interplay between O-GlcNAcylation and phosphorylation in cellular regulation. FEBS Lett 2010, 584, (12), 2526-2538.

18.Ma, J.; Hart, G. W., O-GlcNAc profiling: from proteins to proteomes. Clin. Proteomics 2014, 11, (1), 8.

19.Hahne, H.; Kuster, B., A novel two-stage tandem mass spectrometry approach and scoring scheme for the identification of O-GlcNAc modified peptides. J. Am. Soc. Mass Spectrom 2011, 22, (5), 931-942.

20.Mirgorodskaya, E.; Roepstorff, P.; Zubarev, R. A., Localization of O-glycosylation sites in peptides by electron capture dissociation in a Fourier transform mass spectrometer. Anal. Chem 1999, 71, (20), 4431-4436.

21.Vosseller, K.; Trinidad, J. C.; Chalkley, R. J.; Specht, C. G.; Thalhammer, A.; Lynn, A. J.; Snedecor, 
J. O.; Guan, S.; Medzihradszky, K. F.; Maltby, D. A.; Schoepfer, R.; Burlingame, A. L., O-linked $\mathrm{N}$-acetylglucosamine proteomics of postsynaptic density preparations using lectin weak affinity chromatography and mass spectrometry. Mol. Cell Proteomics 2006, 5, (5), 923-934.

22.Ma, Z. Y.; Skorobogatko, Y.; Vosseller, K., Tandem lectin weak affinity chromatography for glycoprotein enrichment. Methods Mol. Biol 2013, 951, 21-31.

23.Nagel, A. K.; Schilling, M.; Comte-Walters, S.; Berkaw, M. N.; Ball, L. E., Identification of Olinked $\mathrm{N}$-acetylglucosamine (O-GlcNAc)-modified osteoblast proteins by electron transfer dissociation tandem mass spectrometry reveals proteins critical for bone formation. Mol Cell Proteomics 2013, 12, (4), 945-955.

24.Chalkley, R. J.; Thalhammer, A.; Schoepfer, R.; Burlingame, A. L., Identification of protein OGlcNAcylation sites using electron transfer dissociation mass spectrometry on native peptides. Proc. Natl. Acad. Sci. U. S. A 2009, 106, (22), 8894-8899.

25.Trinidad, J. C.; Barkan, D. T.; Gulledge, B. F.; Thalhammer, A.; Sali, A.; Schoepfer, R.; Burlingame, A. L., Global identification and characterization of both O-GlcNAcylation and phosphorylation at the murine synapse. Mol. Cell Proteomics 2012, 11, (8), 215-229.

26.Zhao, P.; Viner, R.; Teo, C. F.; Boons, G. J.; Horn, D.; Wells, L., Combining high-energy C-trap dissociation and electron transfer dissociation for protein O-GlcNAc modification site assignment. J Proteome. Res 2011, 10, (9), 4088-4104.

27.Fardini, Y.; Perez-Cervera, Y.; Camoin, L.; Pagesy, P.; Lefebvre, T.; Issad, T., Regulatory OGlcNAcylation sites on FoxO1 are yet to be identified. Biochem. Biophys. Res Commun 2015, 462, (2), 151-158.

28.Xu, S. L.; Chalkley, R. J.; Maynard, J. C.; Wang, W.; Ni, W.; Jiang, X.; Shin, K.; Cheng, L.; Savage, D.; Huhmer, A. F.; Burlingame, A. L.; Wang, Z. Y., Proteomic analysis reveals O-GlcNAc modification on proteins with key regulatory functions in Arabidopsis. Proc Natl Acad Sci U S A 2017, 114, (8), E1536-E1543.

29.Lee, A.; Miller, D.; Henry, R.; Paruchuri, V. D.; O'Meally, R. N.; Boronina, T.; Cole, R. N.; Zachara, N. E., Combined Antibody/Lectin Enrichment Identifies Extensive Changes in the OGlcNAc Sub-proteome upon Oxidative Stress. J Proteome Res 2016, 15, (12), 4318-4336.

30.Vosseller, K.; Hansen, K. C.; Chalkley, R. J.; Trinidad, J. C.; Wells, L.; Hart, G. W.; Burlingame, A. L., Quantitative analysis of both protein expression and serine / threonine post-translational modifications through stable isotope labeling with dithiothreitol. Proteomics 2005, 5, (2), 388-398.

31.Wells, L.; Vosseller, K.; Cole, R. N.; Cronshaw, J. M.; Matunis, M. J.; Hart, G. W., Mapping sites of O-GlcNAc modification using affinity tags for serine and threonine post-translational modifications. Mol Cell Proteomics 2002, 1, (10), 791-804.

32.Hedou, J.; Bastide, B.; Page, A.; Michalski, J. C.; Morelle, W., Mapping of O-linked beta-Nacetylglucosamine modification sites in key contractile proteins of rat skeletal muscle. Proteomics 2009, 9, (8), 2139-2148.

33.Dehennaut, V.; Lefebvre, T.; Leroy, Y.; Vilain, J. P.; Michalski, J. C.; Bodart, J. F., Survey of OGlcNAc level variations in Xenopus laevis from oogenesis to early development. Glycoconj. $J$ 2009, 26, (3), 301-311.

34.Khidekel, N.; Arndt, S.; Lamarre-Vincent, N.; Lippert, A.; Poulin-Kerstien, K. G.; Ramakrishnan, B.; Qasba, P. K.; Hsieh-Wilson, L. C., A chemoenzymatic approach toward the rapid and sensitive detection of O-GlcNAc posttranslational modifications. J. Am. Chem. Soc 2003, 125, (52), 1616216163.

35.Khidekel, N.; Ficarro, S. B.; Clark, P. M.; Bryan, M. C.; Swaney, D. L.; Rexach, J. E.; Sun, Y. E.; Coon, J. J.; Peters, E. C.; Hsieh-Wilson, L. C., Probing the dynamics of O-GlcNAc glycosylation in the brain using quantitative proteomics. Nat. Chem. Biol 2007, 3, (6), 339-348.

36.Tai, H. C.; Khidekel, N.; Ficarro, S. B.; Peters, E. C.; Hsieh-Wilson, L. C., Parallel identification of O-GlcNAc-modified proteins from cell lysates. J. Am. Chem. Soc 2004, 126, (34), 10500-10501.

37.Kim, E. J., Chemical arsenal for the study of O-GlcNAc. Molecules 2011, 16, (3), 1987-2022.

38.Alfaro, J. F.; Gong, C. X.; Monroe, M. E.; Aldrich, J. T.; Clauss, T. R.; Purvine, S. O.; Wang, Z.; Camp, D. G.; Shabanowitz, J.; Stanley, P.; Hart, G. W.; Hunt, D. F.; Yang, F.; Smith, R. D., Tandem mass spectrometry identifies many mouse brain O-GlcNAcylated proteins including EGF domainspecific O-GlcNAc transferase targets. Proc. Natl. Acad. Sci. U. S. A 2012, 109, (19), 7280-7285.

39.Wang, Z.; Udeshi, N. D.; O'Malley, M.; Shabanowitz, J.; Hunt, D. F.; Hart, G. W., Enrichment and 
site mapping of O-linked $\mathrm{N}$-acetylglucosamine by a combination of chemical/enzymatic tagging, photochemical cleavage, and electron transfer dissociation mass spectrometry. Mol Cell Proteomics 2010, 9, (1), 153-160.

40.Wang, Z.; Udeshi, N. D.; Slawson, C.; Compton, P. D.; Sakabe, K.; Cheung, W. D.; Shabanowitz, J.; Hunt, D. F.; Hart, G. W., Extensive crosstalk between O-GlcNAcylation and phosphorylation regulates cytokinesis. Sci. Signal 2010, 3, (104), ra2.

41.Wang, S.; Yang, F.; Petyuk, V. A.; Shukla, A. K.; Monroe, M. E.; Gritsenko, M. A.; Rodland, K. D.; Smith, R. D.; Qian, W. J.; Gong, C. X.; Liu, T., Quantitative proteomics identifies altered OGlcNAcylation of structural, synaptic and memory-associated proteins in Alzheimer's disease. $J$ Pathol 2017, 243, (1), 78-88.

42.Khidekel, N.; Ficarro, S. B.; Peters, E. C.; Hsieh-Wilson, L. C., Exploring the O-GlcNAc proteome: direct identification of O-GlcNAc-modified proteins from the brain. Proc. Natl. Acad. Sci. U. S. A 2004, 101, (36), 13132-13137.

43.Zeidan, Q.; Wang, Z.; De, M. A.; Hart, G. W., O-GlcNAc cycling enzymes associate with the translational machinery and modify core ribosomal proteins. Mol. Biol. Cell 2010, 21, (12), 19221936.

44.Sakabe, K.; Wang, Z.; Hart, G. W., Beta-N-acetylglucosamine (O-GlcNAc) is part of the histone code. Proc. Natl. Acad. Sci. U. S. A 2010, 107, (46), 19915-19920.

45.Ramirez-Correa, G. A.; Jin, W.; Wang, Z.; Zhong, X.; Gao, W. D.; Dias, W. B.; Vecoli, C.; Hart, G. W.; Murphy, A. M., O-linked GlcNAc modification of cardiac myofilament proteins: a novel regulator of myocardial contractile function. Circ. Res 2008, 103, (12), 1354-1358.

46.Wang, Z.; Park, K.; Comer, F.; Hsieh-Wilson, L. C.; Saudek, C. D.; Hart, G. W., Site-specific GlcNAcylation of human erythrocyte proteins: potential biomarker(s) for diabetes. Diabetes 2009, $58,(2), 309-317$.

47.Cieniewski-Bernard, C.; Montel, V.; Stevens, L.; Bastide, B., O-GlcNAcylation, an original modulator of contractile activity in striated muscle. J. Muscle Res. Cell Motil 2009, 30, (7-8), 281287.

48.Cieniewski-Bernard, C.; Lambert, M.; Dupont, E.; Montel, V.; Stevens, L.; Bastide, B., OGlcNAcylation, contractile protein modifications and calcium affinity in skeletal muscle. Front Physiol 2014, 5, 421.

49.Hedou, J.; Cieniewski-Bernard, C.; Leroy, Y.; Michalski, J. C.; Mounier, Y.; Bastide, B., O-linked $\mathrm{N}$-acetylglucosaminylation is involved in the $\mathrm{Ca} 2+$ activation properties of rat skeletal muscle. $J$. Biol. Chem 2007, 282, (14), 10360-10369.

50.Cieniewski-Bernard, C.; Montel, V.; Berthoin, S.; Bastide, B., Increasing O-GlcNAcylation Level on Organ Culture of Soleus Modulates the Calcium Activation Parameters of Muscle Fibers. PLoS. One 2012, 7, (10), e48218.

51.Stevens, L.; Bastide, B.; Hedou, J.; Cieniewski-Bernard, C.; Montel, V.; Cochon, L.; Dupont, E.; Mounier, Y., Potential regulation of human muscle plasticity by MLC2 post-translational modifications during bed rest and countermeasures. Arch. Biochem. Biophys 2013, 540, (1-2), 125132.

52.Cieniewski-Bernard, C.; Dupont, E.; Richard, E.; Bastide, B., Phospho-GlcNAc modulation of slow MLC2 during soleus atrophy through a multienzymatic and sarcomeric complex. Pflugers Arch 2014, 466, (11), 2139-2151.

53.Lambert, M.; Richard, E.; Duban-Deweer, S.; Krzewinski, F.; Deracinois, B.; Dupont, E.; Bastide, B.; Cieniewski-Bernard, C., O-GlcNAcylation is a key modulator of skeletal muscle sarcomeric morphometry associated to modulation of protein-protein interactions. Biochim. Biophys. Acta General Subjects 2016, 1860, (9), 2017-2030.

54.Cieniewski-Bernard, C.; Bastide, B.; Lefebvre, T.; Lemoine, J.; Mounier, Y.; Michalski, J. C., Identification of O-linked $\mathrm{N}$-acetylglucosamine proteins in rat skeletal muscle using twodimensional gel electrophoresis and mass spectrometry. Mol. Cell Proteomics 2004, 3, (6), 577585 .

55.Hahne, H.; Sobotzki, N.; Nyberg, T.; Helm, D.; Borodkin, V. S.; van Aalten, D. M.; Agnew, B.; Kuster, B., Proteome wide purification and identification of O-GlcNAc-modified proteins using click chemistry and mass spectrometry. J. Proteome. Res 2013, 12, (2), 927-936.

56. Yin, X.; Cuello, F.; Mayr, U.; Hao, Z.; Hornshaw, M.; Ehler, E.; Avkiran, M.; Mayr, M., Proteomics 
analysis of the cardiac myofilament subproteome reveals dynamic alterations in phosphatase subunit distribution. Mol. Cell Proteomics 2010, 9, (3), 497-509.

57.Brosch, M.; Yu, L.; Hubbard, T.; Choudhary, J., Accurate and sensitive peptide identification with Mascot Percolator. J Proteome Res 2009, 8, (6), 3176-81.

58.Vizcaino, J. A.; Csordas, A.; Del-Toro, N.; Dianes, J. A.; Griss, J.; Lavidas, I.; Mayer, G.; PerezRiverol, Y.; Reisinger, F.; Ternent, T.; Xu, Q. W.; Wang, R.; Hermjakob, H., 2016 update of the PRIDE database and its related tools. Nucleic Acids Res 2016, 44, (22), 11033.

59.Pont, F.; Fournie, J. J., Sorting protein lists with nwCompare: a simple and fast algorithm for n-way comparison of proteomic data files. Proteomics 2010, 10, (5), 1091-4.

60.Thomas, P. D.; Campbell, M. J.; Kejariwal, A.; Mi, H.; Karlak, B.; Daverman, R.; Diemer, K.; Muruganujan, A.; Narechania, A., PANTHER: a library of protein families and subfamilies indexed by function. Genome Res 2003, 13, (9), 2129-41.

61.Thomas, P. D.; Kejariwal, A.; Campbell, M. J.; Mi, H.; Diemer, K.; Guo, N.; Ladunga, I.; UlitskyLazareva, B.; Muruganujan, A.; Rabkin, S.; Vandergriff, J. A.; Doremieux, O., PANTHER: a browsable database of gene products organized by biological function, using curated protein family and subfamily classification. Nucleic Acids Res 2003, 31, (1), 334-41.

62.Mi, H.; Guo, N.; Kejariwal, A.; Thomas, P. D., PANTHER version 6: protein sequence and function evolution data with expanded representation of biological pathways. Nucleic Acids Res 2007, 35, (Database issue), D247-52.

63.Vizcaino, J. A.; Deutsch, E. W.; Wang, R.; Csordas, A.; Reisinger, F.; Rios, D.; Dianes, J. A.; Sun, Z.; Farrah, T.; Bandeira, N.; Binz, P. A.; Xenarios, I.; Eisenacher, M.; Mayer, G.; Gatto, L.; Campos, A.; Chalkley, R. J.; Kraus, H. J.; Albar, J. P.; Martinez-Bartolome, S.; Apweiler, R.; Omenn, G. S.; Martens, L.; Jones, A. R.; Hermjakob, H., ProteomeXchange provides globally coordinated proteomics data submission and dissemination. Nat Biotechnol 2014, 32, (3), 223-6.

64.Mi, H.; Muruganujan, A.; Casagrande, J. T.; Thomas, P. D., Large-scale gene function analysis with the PANTHER classification system. Nat Protoc 2013, 8, (8), 1551-66.

65.Mi, H.; Poudel, S.; Muruganujan, A.; Casagrande, J. T.; Thomas, P. D., PANTHER version 10: expanded protein families and functions, and analysis tools. Nucleic Acids Res 2016, 44, (D1), D336-42.

66.Cieniewski-Bernard, C.; Dupont, E.; Deracinois, B.; Lambert, M.; Bastide, B., Multiplexed Detection of O-GlcNAcome, Phosphoproteome, and Whole Proteome within the Same Gel. Front Endocrinol. (Lausanne) 2014, 5, 184.

67.Paulin, D.; Li, Z., Desmin: a major intermediate filament protein essential for the structural integrity and function of muscle. Exp. Cell Res 2004, 301, (1), 1-7.

68.Heimburg, T.; Schuenemann, J.; Weber, K.; Geisler, N., Specific recognition of coiled coils by infrared spectroscopy: analysis of the three structural domains of type III intermediate filament proteins. Biochemistry 1996, 35, (5), 1375-82.

69.Hnia, K.; Ramspacher, C.; Vermot, J.; Laporte, J., Desmin in muscle and associated diseases: beyond the structural function. Cell Tissue Res 2014.

70.Bar, H.; Goudeau, B.; Walde, S.; Casteras-Simon, M.; Mucke, N.; Shatunov, A.; Goldberg, Y. P.; Clarke, C.; Holton, J. L.; Eymard, B.; Katus, H. A.; Fardeau, M.; Goldfarb, L.; Vicart, P.; Herrmann, H., Conspicuous involvement of desmin tail mutations in diverse cardiac and skeletal myopathies. Hum Mutat 2007, 28, (4), 374-86.

71.Krishnamoorthy, V.; Donofrio, A. J.; Martin, J. L., O-GlcNAcylation of alphaB-crystallin regulates its stress-induced translocation and cytoprotection. Mol Cell Biochem 2013, 379, (1-2), 59-68.

72.Elliott, J. L.; Der, P. M.; Prescott, A. R.; Jansen, K. A.; Koenderink, G. H.; Quinlan, R. A., The specificity of the interaction between alphaB-crystallin and desmin filaments and its impact on filament aggregation and cell viability. Philos. Trans. R. Soc. Lond B Biol. Sci 2013, 368, (1617), 20120375.

73.Nicholl, I. D.; Quinlan, R. A., Chaperone activity of alpha-crystallins modulates intermediate filament assembly. EMBO J 1994, 13, (4), 945-53.

74.Costa, M. L.; Escaleira, R.; Cataldo, A.; Oliveira, F.; Mermelstein, C. S., Desmin: molecular interactions and putative functions of the muscle intermediate filament protein. Braz. J Med. Biol Res 2004, 37, (12), 1819-1830.

75.Perng, M. D.; Cairns, L.; van den, I. J.; Prescott, A.; Hutcheson, A. M.; Quinlan, R. A., 
Intermediate filament interactions can be altered by HSP27 and alphaB-crystallin. J. Cell Sci 1999, 112 ( Pt 13), 2099-2112.

76.Houck, S. A.; Landsbury, A.; Clark, J. I.; Quinlan, R. A., Multiple sites in alphaB-crystallin modulate its interactions with desmin filaments assembled in vitro. PLoS. One 2011, 6, (11), e25859.

77.Arrigo, A. P.; Simon, S.; Gibert, B.; Kretz-Remy, C.; Nivon, M.; Czekalla, A.; Guillet, D.; Moulin, M.; Diaz-Latoud, C.; Vicart, P., Hsp27 (HspB1) and alphaB-crystallin (HspB5) as therapeutic targets. FEBS Lett 2007, 581, (19), 3665-3674.

78.Arndt, V.; Dick, N.; Tawo, R.; Dreiseidler, M.; Wenzel, D.; Hesse, M.; Furst, D. O.; Saftig, P.; Saint, R.; Fleischmann, B. K.; Hoch, M.; Hohfeld, J., Chaperone-assisted selective autophagy is essential for muscle maintenance. Curr Biol 2010, 20, (2), 143-8.

79.Ulbricht, A.; Eppler, F. J.; Tapia, V. E.; van der Ven, P. F.; Hampe, N.; Hersch, N.; Vakeel, P.; Stadel, D.; Haas, A.; Saftig, P.; Behrends, C.; Furst, D. O.; Volkmer, R.; Hoffmann, B.; Kolanus, W.; Hohfeld, J., Cellular mechanotransduction relies on tension-induced and chaperone-assisted autophagy. Curr Biol 2013, 23, (5), 430-5.

80.Rosati, A.; Graziano, V.; De Laurenzi, V.; Pascale, M.; Turco, M. C., BAG3: a multifaceted protein that regulates major cell pathways. Cell Death Dis 2011, 2, e141.

81.Tskhovrebova, L.; Trinick, J., Roles of titin in the structure and elasticity of the sarcomere. $J$. Biomed. Biotechnol 2010, 2010, 612482.

82.Kontrogianni-Konstantopoulos, A.; Ackermann, M. A.; Bowman, A. L.; Yap, S. V.; Bloch, R. J., Muscle giants: molecular scaffolds in sarcomerogenesis. Physiol Rev 2009, 89, (4), 1217-1267.

83.Bouameur, J. E.; Favre, B.; Fontao, L.; Lingasamy, P.; Begre, N.; Borradori, L., Interaction of plectin with keratins 5 and 14: dependence on several plectin domains and keratin quaternary structure. J Invest Dermatol 2014, 134, (11), 2776-2783.

84.Bouameur, J. E.; Schneider, Y.; Begre, N.; Hobbs, R. P.; Lingasamy, P.; Fontao, L.; Green, K. J.; Favre, B.; Borradori, L., Phosphorylation of serine 4,642 in the C-terminus of plectin by MNK2 and PKA modulates its interaction with intermediate filaments. J Cell Sci 2013, 126, (Pt 18), 4195207.

85.Favre, B.; Schneider, Y.; Lingasamy, P.; Bouameur, J. E.; Begre, N.; Gontier, Y.; SteinerChampliaud, M. F.; Frias, M. A.; Borradori, L.; Fontao, L., Plectin interacts with the rod domain of type III intermediate filament proteins desmin and vimentin. Eur J Cell Biol 2011, 90, (5), 390-400. 
Table I: Overall evaluation of the O-GIcNAc mapping efficiency after extensive fractionation.

3 The non-linked peptides on agarose beads and the peptides resulting from beta-elimination of peptides covalently linked to agarose beads were sequenced using mass spectrometry. The number of sequenced peptides (and the percentage of peptides containing dehydrated serine and threonine) and the corresponding number of identified proteins were indicated for each fraction (whole extract, WE; non-fractionated cytosol-enriched extract, CYT; fractionated cytosol-enriched extract, fCYT). The efficiency factor was determined as the ratio of sequenced peptides or identified proteins in fCYT fraction comparing with the WE or the CYT fractions.

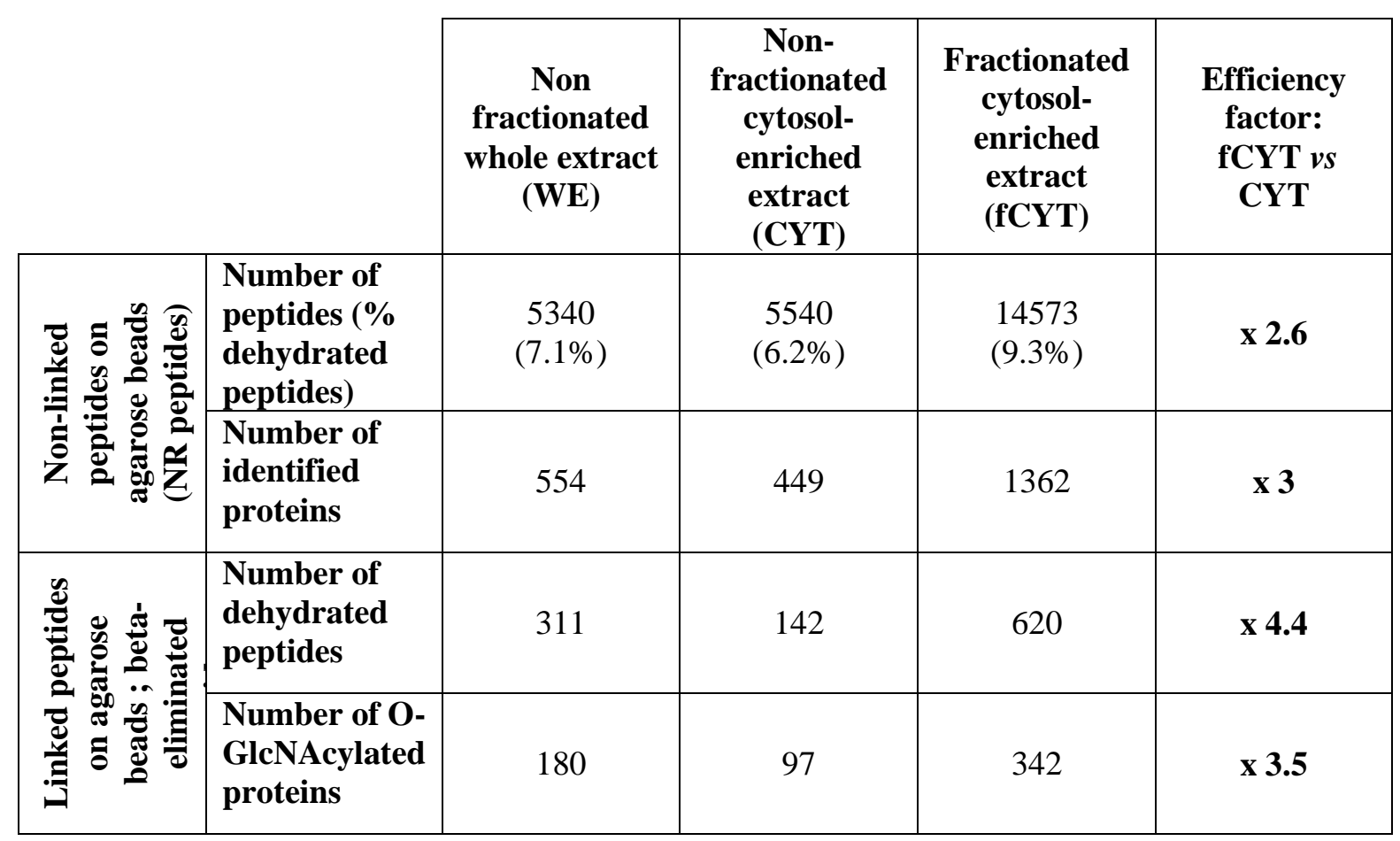

12

Figure 1: Representative scheme of the workflow applied prior to the click chemistry. The protein fractions indicated in bold italic on figure 1 correspond to fraction submitted to azide-alkyne click chemistry and analysed on mass spectrometry. 


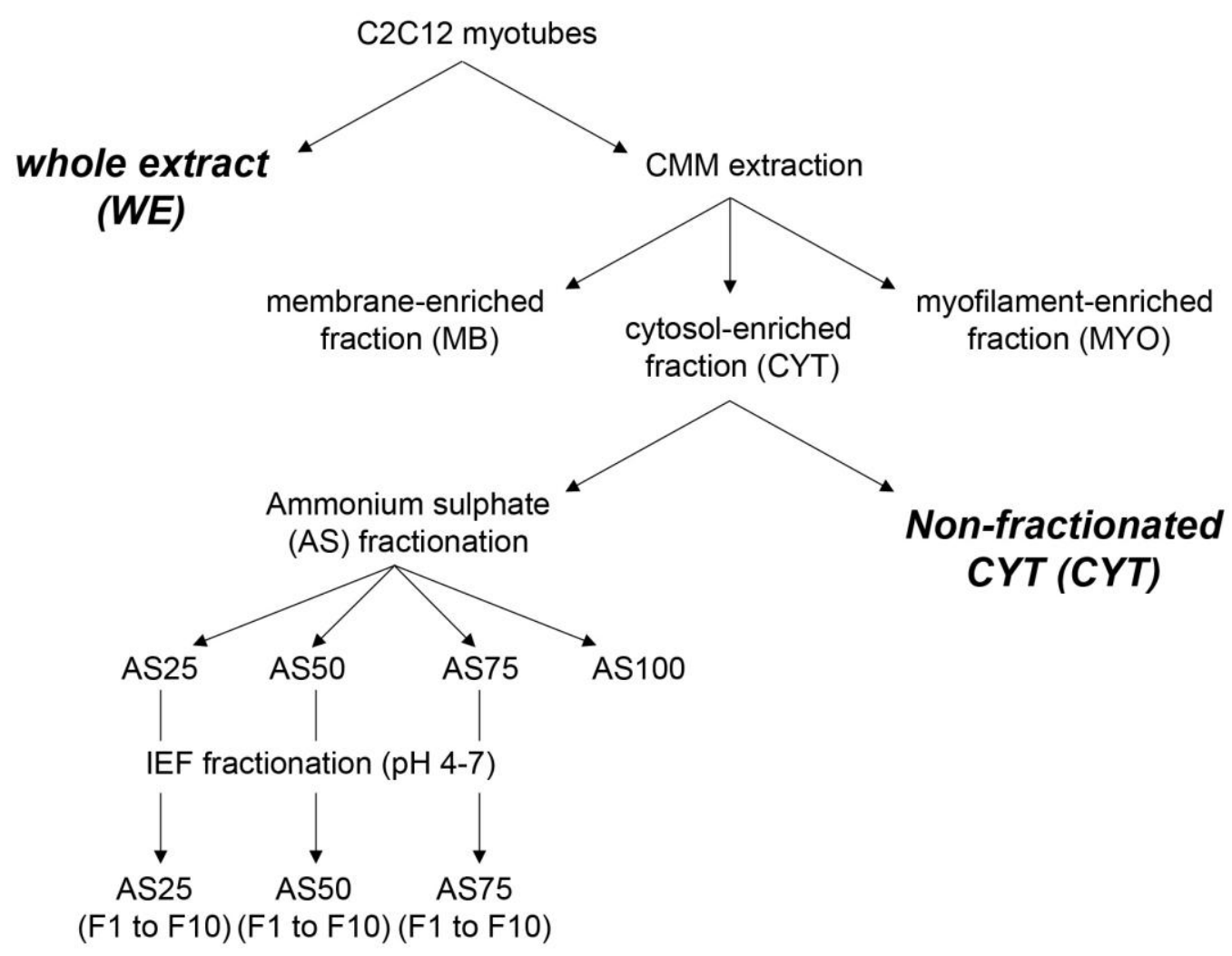

Fractionated CYT (fCYT)

Figure 1

2 Figure 2: Efficiency of the protein fractionation. (A) Protein profiles of the differential extraction.

3 Twenty $\mu \mathrm{g}$ of proteins corresponding to whole extract (WE), cytosol-enriched fraction (CYT),

4 membrane-enriched fraction (MB) and myofilament-enriched fraction (MYO) were separated on 7.5\%

5 Mini-PROTEAN TGX SF Precast Gels and visualized according to Stain-free technology. (B) Protein

6 profiles resulting from ammonium sulphate (AS) precipitation of cytosol-enriched extract. Twenty $\mu \mathrm{g}$

7 of proteins corresponding to whole extract (WE), AS25, AS50, AS75 and AS100 (corresponding to 
1 final concentration of ammonium sulphate (AS)) were separated on AnykD Mini-PROTEAN TGX SF 2 Precast Gels and visualized according to Stain-free technology. (C) Protein profiles of the 10 fractions 3 resulting from MicroRotofor separation of proteins from AS25, AS50 and AS75 fractions, according to 4 their isoelectric point on $\mathrm{pH}$ range of 4 to 7 . Ten $\mu \mathrm{l}$ of each fraction were separated on AnykD Mini5 PROTEAN TGX SF Precast Gels and visualized according to Stain-free technology. The percentage of 6 proteins compared with the non-fractionated extract were indicated above each gel images. The $\mathrm{pH}$ of 7 each fraction was indicated on supplemented table I. 


\section{A Fractionated protein extraction}

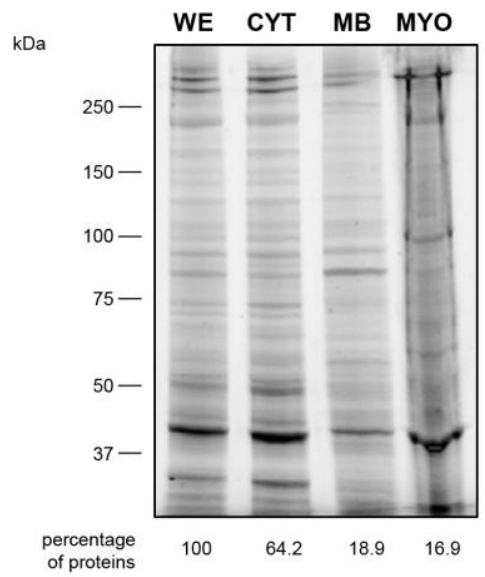

B Ammonium sulphate precipitation (AS) of cytosol-enriched fraction

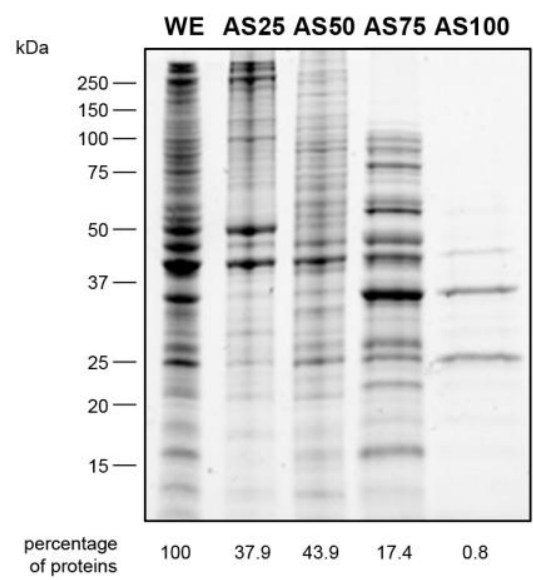

C IEF fractionation (pH 4-7) of AS25, A50 and AS75

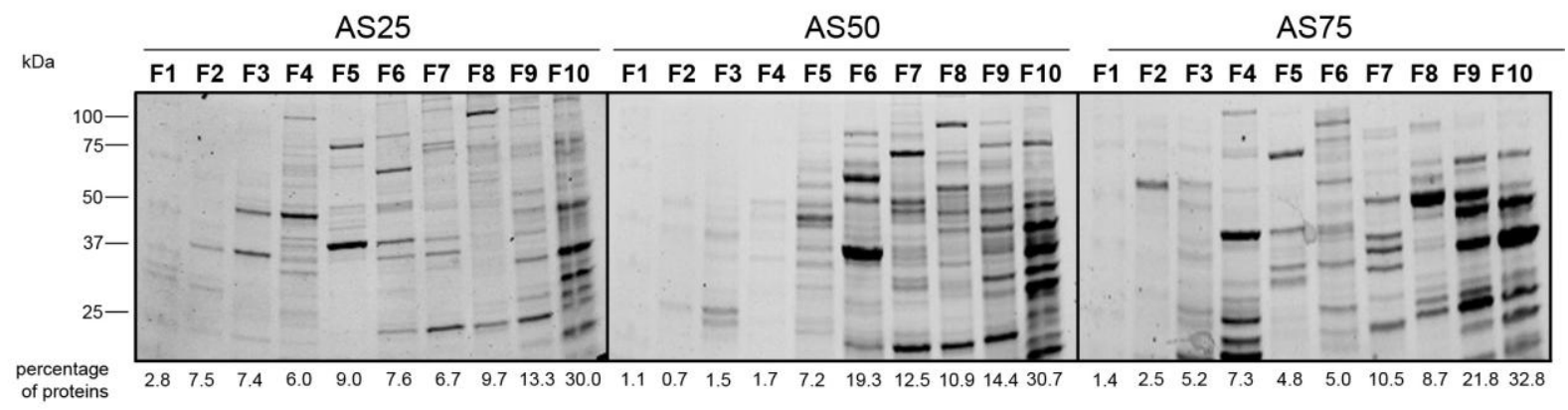

\section{Figure 2}

2 Figure 3: Classification of the $\mathbf{3 4 2}$ proteins identified from peptides released from agarose beads 3 by beta-elimination. The classification was done using the PANTHER classification system (Protein 4 Analysis THrough Evolutionary Relationships, http://www.pantherdb.org/). (A) Classification of 


\section{A Molecular Function}

Transporter activity

Translation regulator activity

Catalytic activity

Channel regulator activity

Receptor activity

Signal transducer activity

Antioxidant activity

Structural molecule activity

Binding

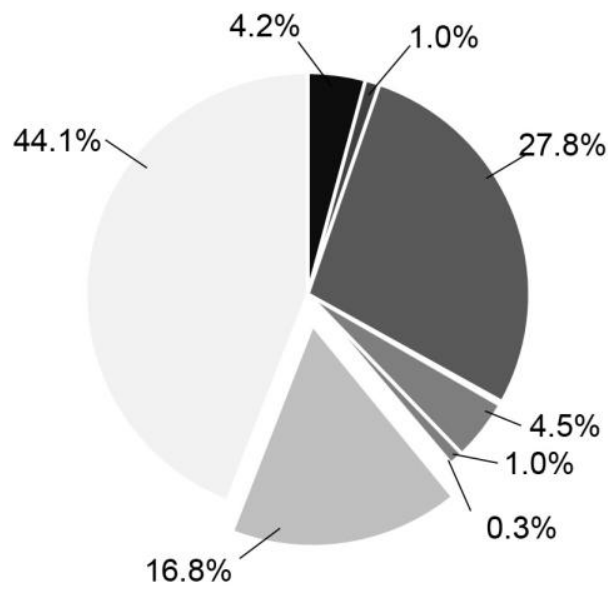

\section{B Protein Class}

Structural proteins

Enzymatic activities

Nucleic acid metabolism

Cytoskeletal proteins and chaperones

Transporter and binding proteins

Cell adhesion molecule

Signalling proteins

Others

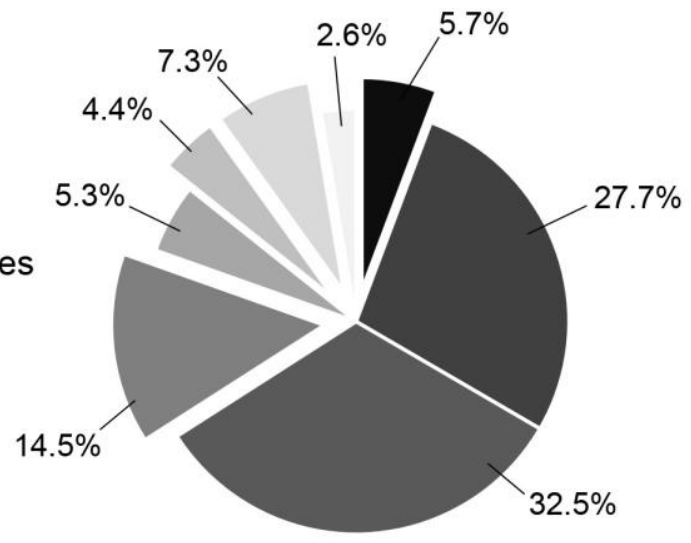

Figure 3

\section{SUPPLEMENTED TABLES}

3

4 Table I: Measurement of $\mathbf{p H}$ of fractions resulting from isoelectric separation using

5 MicroRotofor cell on pH 4-7 range. The $\mathrm{pH}$ of each fraction is indicated as value \pm SD (standard

6 deviation). The fraction F1 corresponds to the more acidic fraction, while the fraction F10 corresponds 
to the more basic one.

2

3 Table II, IV and VI: Data files corresponding to the identification of proteins from sequencing of 4 peptides released from agarose beads by beta-elimination. These peptides correspond to O-

5 GlcNAcylated peptides (BE, beta-eliminated peptides). Table II corresponds to proteins identified 6 from whole extract (WE), table IV to proteins identified from cytosol-enriched extract (CYT), and 7 table VI to proteins identified from fractionated cytosol-enriched extract (fCYT).

8

Table III, V and VII: Data files corresponding to the identification of proteins from sequencing 10 of peptides released from agarose beads by trypsin. These peptides correspond to non-O11 GlcNAcylated peptides (NR, non-retained peptides), but they belong O-GlcNAcylated proteins 12 covalently linked to agarose beads. Table III corresponds to proteins identified from whole extract 13 (WE), table V to proteins identified from cytosol-enriched extract (CYT), and table VII to proteins 14 identified from fractionated cytosol-enriched extract (fCYT). 